\title{
Kirkpatrick Application of Batik Training for International Students
}

\author{
Jozua Ferjanus Palandi, Ni Ketut Kertiasih, Khaidir Rahman, Nyoman Arya Wigraha, \\ Lativa Hartiningtyas, Subari, Rini Agustina, Muhammad Imran \\ $\left\{\right.$ jozuafp@stiki.ac.id ${ }^{1}$, Kertiasih@undiksha.ac.id², khaidir@akba.ac.id ${ }^{3}$, wigraha@undiksha.ac.id ${ }^{4}$, \\ lativa@unublitar.ac.id ${ }^{5}$, rini@unikama.ac.id ${ }^{6}$,imran@akba.ac.id $\left.{ }^{7}\right\}$ \\ Teknik Informatika STIKI, Indonesia ${ }^{1,6}$, Teknik Informatika UNDIKSHA, Indonesia ${ }^{2,4}$, Teknik \\ Mesin, AKBA, Indonesia ${ }^{3,8}$, Teknik Informatika UNU, Indonesia ${ }^{5}$, Teknik Informatika UNIKAMA, \\ Indonesia ${ }^{7}$
}

\begin{abstract}
Batik training which is the object of this research is part of the cultural camp activities conducted by STIKI. This activity was carried out as an effort to improve campus image and promotion. In addition, this activity is part of the internationalization of STIKI. This program was held in 2016 by the Office of International Affairs which was attended by international students. The international students involved ten people, they came from four universities in East Java. The purpose of this study was to determine the effectiveness of batik training based on Four Level Kirkpatrick's theory. While the method used in this research is a descriptive method. The results showed that the cultural camp activities held were effective. This can be seen from the important activities of batik training that worked well. The results of the evaluation conducted by the OIA STIKI received a positive response from the committee, instructors, and participants.
\end{abstract}

Keywords: international students, cultural camp, four levels, Kirkpatrick, training.

\section{Introduction}

A cultural camp was organized by the Office of International Affairs of STIKI which was part of a collaborative program between universities. The activity was supported by the Ministry of Research, Technology and Higher Education through a grant for Office of International Affairs. Cultural Camp was important as an effort to introduce Indonesian culture, to preserve Indonesian culture, to become a global means of communication for participants from various cultural and linguistic backgrounds, to instil internationalization insights for participants, and to provide insight into how to become citizens of the world.

One of the ways carried out by institutions in the effort to introduce Indonesian culture to international students is to provide batik training. The training essentially introduces, preserves, and communicates culture. In addition, this event also instilled insight into internationalization. This kind of activity is a management function that needs to be carried out periodically. This is not just a training but is a development of human resources in an institution. Human resources in an institution should be able to manage other resources to support the achievement of organizational goals [1] and optimize organizational performance through planned employees satisfaction [2]. Likewise, this training activity. Therefore, every human resource must be managed properly so that they receive knowledge that suits their needs, in this case, the 
resources at STIKI should be able to support training activities held by the Office of International Affairs of STIKI or other units that need it. Specifically, the training process is a series of actions or efforts carried out in a continuous [3], gradual, and integrated manner. Organizing training in an institution definitely requires a lot of effort, time [3], and costs. Therefore, the management who has the authority in decision making needs to know that an activity or training is a form of investment from the institution [4].

To convince the decision maker that a training program is an investment, it is not enough to just explain the aspects of preparation and technical implementation. The expected results must appear after the training is held. The important part is to make the institution understand that the implementation of training is not as an expenditure but really an investment that has a significant effect on the image or promotion of the institution. Another reason to consider is that the training activities could support the achievement of the institutional vision.

To find out the results, impacts, and benefits obtained from batik training to international students, it is necessary to evaluate the training. After the training is given, how far the benefit of the training to change or improve performance or competence with the institution is. This is important because it is not certain that training that has absorbed large funds can provide effective results in accordance with the training objectives. In general, the objective of training is to optimally improve the knowledge, skills [5], and behavior/attitude [6] of the trainees.

The International Affairs Office of STIKI is an important unit that provides services to students about internship and student exchange opportunities in the STIKI environment. In addition, the Office of International Affairs of STIKI also plays a role in the field of English language training, cooperation with universities abroad, and internationalization programs. Office of International Affairs of STIKI has successfully held training for international students in cultural camp activities and has opened opportunities for students to consult about internships or lectures abroad. Based on observations that have been made, the Office of International Affairs of STIKI has not optimally evaluated the previous training. Training evaluation is an effort to find out the level of success of the program or to find out the implementation of a policy [7]. Thus training evaluation activities refer to goals [8] as a measure of success.

The implementation of a program must always be evaluated to see the extent to which the program has achieved its objectives. Learning processes need to be harmonized so that learning conditions can support the objectives so the optimal results are achieved as expected [9]. Without evaluation, the results of the training cannot be seen. Previously, policies related to training programs were never supported by data. Therefore, this training evaluation provides data and information as well as recommendations for policymakers to decide whether training will continue, improve or stop a program. In addition, the evaluation is intended to find out the benefits of conducting training. Based on this background, this research was conducted on the evaluation of batik training for international students. The evaluation was carried out using The Four Levels theory developed by Kirkpatrick.

\subsection{The Four Levels}

Important components of the training implementation cycle are evaluation components [10]. This stage is important because at this stage it provides feedback at each stage in the training implementation cycle. Basically, evaluation has three objectives, namely to improve the program (including training implementation strategies), to determine whether a training program must be stopped or continue, and to provide training program values. Evaluation of a training is an inseparable part of the training itself and that evaluation is an activity that must be carried out so that overall training can take place effectively. In 1959 Kirkpatrick produced a 
theory of training evaluation through his writing in the American Society for Training and Development Journal, a theory known as The Four Levels Techniques for Evaluating Training Programs. Based on this theory, there are four levels in training evaluation [11]:

Reaction. Evaluation at this level measures the reaction of participants' satisfaction with the training. The things that were evaluated at this level included training materials, trainers, facilities provided, time of administration, and the methods used. Evaluation at this level is useful to provide feedback for managerial, organizers of training, and material providers for improving the next training implementation.

Learning. Evaluation at this level measures the extent to which participants understand training material delivered in three competency domains, namely knowledge, skills, and attitude. Evaluation at this level emphasizes how far the learning of participants on training material in the context of increasing competence.

Behavior Evaluation at this level measures the extent to which participants apply or implement an understanding of the three competency domains (knowledge, skills, and attitude) acquired in their work environment. In addition, the evaluation at this level is not enough to just measure the changes that occur in the ex-participant behavior, but furthermore, it needs to be evaluated as far as the changes that occur can be applied in their daily lives.

Result Evaluation at this stage measures how much impact the implementation of training has on job performance or expected end results. This level evaluation is the most important and the most difficult evaluation carried out because it measures the extent to which the training carried out has an impact/result on improving the performance of the ex-participants, work units, and the organization as a whole.

To deepen understanding of effectiveness in training, in general, an institution relies on Kirkpatrick's level 1 reaction and level 2 learning theory. According to Kirkpatrick, the first stage of evaluation in the effectiveness evaluation model described the measurement of learning programs. In this case, the management can measure participants' attitudes and satisfaction with the program. The second level in Kirkpatrick's effectiveness theory was the level of learning evaluation. This level relies more on the results of observation and evaluation of conducted training by looking at the test results after the completion of the education and training program.

In addition to measuring the effectiveness of a training, it can compare between the results of Kirkpatrick's evaluation of level 1 reaction and level 2 learning theory with the costs arising from the implementation of a training. The implementation of effective training is able to increase the knowledge, skills [11], and attitudes of the trainees according to the needs of the organization. To achieve the objectives of effective training implementation, several training methods have been prepared in accordance with the results to be achieved by the organization. The preparation of the training method, not only pay attention to the element of effectiveness but also the element of cost. This is because of the members of the organization are seen as assets that must provide feedback for the organization so that any costs incurred by the organization for training members of the organization are expected to generate returns that are greater than the costs incurred.

\subsection{The process of Batik}

Nggambar (drawing). The first step is to make a batik design which is usually called nggambar. Another term commonly used is nyorek or some call it molani. In determining motives, everyone has their own sense of tastes. Some prefer to make their own motives, but others prefer to follow the common motives that already exist. The motif that is often found in Indonesia itself is batik which is divided into 2 types. The first is classic batik, which emphasizes 
the use of a lot of symbols. The second is coastal batik with natural features such as pictures of flowers or butterflies. Making this pattern or motif must use a pencil.

Nyanthing (gluing the wax). One unique process in making batik is nyanthing. Nyanthing is the process of gluing the wax onto a white cloth that has previously been given a batik pattern [12]. This process requires perseverance and patience while doing it. The process requires time, depending on patterns and the motif of batik. In the process of making batik, to get good quality, this process must be done very diligently, sabra, and takes time to produce beautiful and beautiful batik works. The result of the combination of artistic creativity and patience of the batik makers has also been proven to be able to produce works that are global. Aside from being part of the process of making batik, nyanthing activities can also be used as a positive activity to train participants in creativity, perseverance, and patience.

Colet (coloring). Nyolet/Coletan is giving a color to the batik cloth [12], locally with a dyed solution where the color of the colored area is limited by wax lines so that the color does not seep in other areas. Dyestuffs that are often used are dyestuff rapid.

Njemur (drying). Wet conditions after the cloth dipped in a container that has been given a dye solution needs to be dried. This process is called njemur. This drying process is done repeatedly. After drying, the cloth is dipped again to get maximum results or the desired color. This drying should not be under direct sunlight, just in the wind.

Nglorot (releasing the wax). Nglorot is the final stage in the process of making a piece of batik cloth or stamp batik that uses a color border (wax). In this stage, the batik releases the entire wax by inserting a cloth that has dry enough to color in boiling water. Once removed, the cloth is rinsed with clean water and then aired until dry. The initial process until the final process can involve several people, and the completion of a process stage also takes a long time.

\section{Method}

\subsection{Respondents}

Participants in this batik study are international students studying in Indonesia. They are active students from four universities in East Java, from Malang and Surabaya. Universities in Malang in question are Widyagama University Malang (UWM) and State University of Malang (UM), while universities from Surabaya are Airlangga University (Unair) and Sepuluh Nopember Institute of Technology Surabaya (ITS). The participants of cultural camp were from different countries who studied in different Indonesian universities: two students from UNAIR, two students from UWG, three students from ITS and three students from UM.

\subsection{Instrument}

Because the purpose of this research is to find out the reaction of batik training participants and the effectiveness of cultural camp activities, then this research uses descriptive qualitative design. The instrument for collecting data in this study uses an open-ended questionnaire. The purpose of distributing this questionnaire is to get an overview of the reaction of participants in batik training during STIKI. Observations are also made at each session of the six scheduled sessions. This observation was carried out to find out directly their reaction when the batik training was held. 


\subsection{Procedure}

Questionnaires were distributed on the fifth day of the six days of training where training began on 21 November to 26 November 2016. From the six days of this event, this batik training required six sessions with four days. This training is intended for participants who are international students from four universities in Malang and Surabaya. Questionnaires were distributed to ten participants who attended all training sessions. Questionnaires were answered and collected on the same day. Observations on participants' activities were carried out both in the classroom and outside the classroom.

\subsection{Data Analysis}

Data collected from questionnaires and observations were analyzed descriptively. Data analysis basically has been done since the activity began. Because this research uses the descriptive qualitative method, while the inductive analysis is used to analyze the data. This inductive method is used to obtain conclusions from facts and data collected through questionnaires and observations.

\section{Result And Discussion}

Table 1. Costs

\begin{tabular}{|c|c|c|}
\hline $\begin{array}{l}\text { Activity / Activity Category / Type of } \\
\text { Shopping / Shopping Details }\end{array}$ & Costs & $\%$ \\
\hline \multicolumn{3}{|l|}{ ADMINISTRATION } \\
\hline Amount of administration & $1,400,000$ & $3.29 \%$ \\
\hline \multicolumn{3}{|l|}{ REFRESHMENT } \\
\hline Amount of refreshment & $9,687,500$ & $22.75 \%$ \\
\hline \multicolumn{3}{|l|}{ EXPENDITURE } \\
\hline Amount of expenditure & $4,150,000$ & $9.75 \%$ \\
\hline \multicolumn{3}{|l|}{ EVENT } \\
\hline Amount of all event & $12,630,000$ & $29.66 \%$ \\
\hline \multicolumn{3}{|l|}{ PUBLICATION \& DOCUMENTATION } \\
\hline Amount of publication \& documentation & $6,225,000$ & $14.62 \%$ \\
\hline \multicolumn{3}{|l|}{ TRANSPORTATION \& ACCOMODATION } \\
\hline Amount of transportation \& accomodation & $8,490,000$ & $20 \%$ \\
\hline Total amount of Cultural Camp & $42,582,500$ & $100 \%$ \\
\hline
\end{tabular}

\subsection{Cost of Organizing a Cultural Camp}

Based on the data obtained by the researchers, in organizing this Cultural camp there are six components of costs that are part of the total cost of the overall activity. The six components of costs are secretarial, consumption, treasurer, events, publications \& documentation, and transportation \& accommodation. The component of overhead costs in this study was not included in the components of costs incurred for organizing cultural camp activities. This is due 
to the difficulty in determining the costs arising from matters that are not directly related to the implementation of activity programs besides being not specifically budgeted. The overall financing of the cultural camp activities is based on the Higher Education Internationalization Grant Fund from the Ministry of Research, Technology and Higher Education.

In line with the theory that the biggest component of the implementation of an activity is the event component [13]. In this case, the use of funds is up to $29.66 \%$. This can be seen in Table 1 regarding the details of event costs. While the biggest expenditure is the consumption component. This shows that the implementation of this activity, the consumption component includes components that use the second largest budget after the event component.

\subsection{Reaction of the Participants}

Reaction is an attitude that arises from participants arising due to a condition faced [14]. The measurement of participants' reactions to this activity was carried out by distributing questionnaires to cultural camp participants after completing the activities. The number of respondents to measure the reaction of participants to this activity is ten people.

The questionnaire consisted of thirty-four questions that measured participants' reactions to the program, instructors, materials, refreshment, transportation, accommodation, facilities, and committees. The reaction of participants to the overall cultural camp activities can be seen from the answers to the questionnaires they have filled out.

Their answers showed that they were very satisfied with the implementation of the event. Participants feel they get a lot of knowledge and experience from the implementation of this cultural camp activity.

Based on the results of the study, it was shown that the majority of the training participants had a good reaction to the implementation of the Cultural camp. When viewed as a whole, the percentage of participants who answered very satisfied was more than the percentage of participants who answered satisfied. This fact shows that the reaction of participants to the implementation of this activity was very good.

A training activity is said to be effective if the knowledge, skills, and behavior of the trainees increase after the learning process [15]. In accordance with Donald L Kirkpatrick's level 2 learning evaluation theory, what is used as a reference to find out the effectiveness of training activities is the result of their learning after participating in batik training, namely by seeing the products they produce after the cultural camp program is completed, especially in batik training activities.

After conducting a comprehensive evaluation that includes level one to level four evaluations based on Kirkpatrick's The Four Levels Techniques for Evaluating Training Programs, the results obtained from these activities are as follows. The success of a training can be seen from the three domains of competence (knowledge, skills, and attitudes) which are things that can be taught in a training. Therefore, the evaluation of batik training emphasizes how far the learning of the training participants on five important elements in the batik process in the context of improving their competence. Based on observations and interviews with trainees it can be concluded that the objectives of this training activity have been achieved. Starting from the first goal, namely the effort to introduce Indonesian culture to international students, preserve Indonesian culture, become a means of global communication for participants from various cultural and linguistic backgrounds, instill internationalization insights for participants, and arrive at the final goal of providing insight into how become citizens of the world, everything has been conveyed effectively. 
While the review in terms of benefits, the Office of International Affairs of STIKI through needs analysis that has been identified before the activity starts, can state that this training program can improve the function of the Office of International Affairs of STIKI in the internationalization program. In terms of activities, the implementation of this cultural camp activity has been included in the domain of university internationalization. Whereas in terms of the results of its implementation, the aim of introducing Indonesian culture to international students through the activities of this cultural camp has also proceeded according to plan.

\section{Conclusion}

By applying Kirkpatrick, the results of the research that has been done related to the evaluation of the training activities, it can be concluded as follows: 1) Based on the total recapitulation of the total cost of cultural camp activities, it can be said that the budget costs are well absorbed, 2) Based on the results of research conducted on ten training participants, it was shown that the participants were very satisfied with the implementation of the batik training program, 3) Based on the results of research conducted on training participants, it shows that the training activities have been going well.

\section{References}

[1] Z. Alakoç Burma, "Human Resource Management and Its Importance for Today's Organizations,” Int. J. Educ. Soc. Sci., vol. 1, no. 2, pp. 85-93, 2014.

[2] R. J. Ogedegbe, "Achieving Organisational Objectives Through Human Resource Management Practices,” Eur. J. Bus. Manag., vol. 6, no. 16, pp. 18-23, 2014.

[3] P. Nischithaa and M. V. A. L. N. Rao, "The Importance of Training and Development Programmes in Hotel Industry,” Int. J. Bus. Adm. Res. Rev., vol. 1, no. 5, pp. 50-56, 2014.

[4] J. Landeta, J. Barrutia, J. Hoyos, and A. Araujo, "Initiatives for the Improvement of Continuous Management Training," Cuad. Gest., vol. 15, no. 1, pp. 61-92, 2015.

[5] M. R. A. Salah, "The Impact of Training and Development on Employees Performance," Int. J. Manag. Sci. Bus. Res., vol. 5, no. 7, pp. 36-70, 2016.

[6] M. R. Karim, K. N. Huda, and R. S. Khan, "Significance of Training and Post Training Evaluation for Employee Effectiveness: An Empirical Study on Sainsbury's Supermarket Ltd, UK," Int. J. Bus. Manag., vol. 7, no. 18, pp. 141-148, 2012.

[7] H. Topno, "Evaluation of Training and Development: An Analysis of Various Models," IOSR J. Bus. Manag., vol. 5, no. 2, pp. 16-22, 2012.

[8] S. Dahiya and A. Jha, "Review of Training Evaluation," Int. J. Comput. Sci. Commun., vol. 2, no. 1, pp. 11-16, 2011.

[9] J. F. Palandi, S. Aminah, and Z. E. Pudyastuti, "Pengembangan Aplikasi Web E-Learning untuk Pendidikan Anti Korupsi Menggunakan Moodle,” J. INOVTEK POLBENG - SERI Inform., vol. 2, no. 2, pp. 173-181, 2017.

[10] D. L. Kirkpatrick and J. D. Kirkpatrick, Evaluating Training Programs, 2nd ed. San Fransisco, CA: Berrett-Koehler, 1998.

[11] S. Farjad, "The Evaluation Effectiveness of Training Courses in University by Kirkpatrick Model (Case Study: Islamshahr University),” Procedia - Soc. Behav. Sci., vol. 46, no. 2012, pp. 2837 2841, 2012.

[12] S. P. Adhi, "Karakteristik Motif Batik Kendal Interpretasi dari Wilayah dan Letak Geografis," J. Imajin., vol. X, no. 1, pp. 51-60, 2016.

[13] R. R. Munajatisari, “Analisis Efektivitas Metode Pelatihan Klasikal dan E-Learning,” J. Adm. Bisnis, vol. 10, no. 2, pp. 173-185, 2014. 
[14] Ö. G. Ulum, "Program Evaluation through Kirkpatrick’s Framework," Pacific Bus. Rev. Int. J., vol. 8, no. 1, pp. 106-111, 2015.

[15] N. S. Borate, Gopalkrishna, and S. L. Borate, "A Case Study Approach for Evaluation of Employee Training Effectiveness and Development Program," in Proceedings of the Second International Conference on Global Business, Economics, Finance and Social Sciences (GB14 Conference), 2014, no. July, pp. 1-16. 